\title{
Cytotoxicity of catechol towards human glioblastoma cells via superoxide and reactive quinones generation
}

\section{Citotoxicidade do catecol para células de glioblastoma humano via geração de superóxido e quinonas reativas}

Marco Roberto Guimarães Pereira; Elineusa Silva de Oliveira; Flávio Augusto Guerreiro Aragão de Villar; Maria Socorro Grangeiro; Júlia Fonseca; Ana Rita Silva; Maria de Fátima Dias Costa; Sílvia Lima Costa; Ramon dos Santos El-Bachá

\section{key words abstract}

Catechol

Cytotoxicity

It is known that the exposure to benzene in the petroleum industry causes lympho-haematopoietic cancer among workers. However, there is little data concerning the toxicity of benzene to the central nervous system. Benzene easily penetrates the brain where it is metabolized to catechol. Since catechol 1,2-dihydroxybenzene

Glioblastoma autoxidizes in physiological phosphate buffer, we hypothesized that it could be toxic towards glial cells due to the generation of reactive oxygen species and quinones. In this work we studied the cytotoxic properties of catechol towards human glioblastoma cells. We found that catechol was toxic towards Superoxide these cells after 72 hours and this toxicity was related to the formation of quinones. Catechol at $230 \mu \mathrm{M}$ killed $50 \%$ of cells. The catechol-induced cytotoxicity was prevented by the addition of $100 \mathrm{U}$ superoxide dismutase, which also inhibited the formation of quinones. These data suggest that catechol induces cytotoxicity via the extracellular generation of superoxide and quinones.

Sabe-se que a exposição de trabalhadores ao benzeno na indústria petrolifera é uma causa de câncer do sistema linfo-hematopoiético. Pouco se sabe, contudo, a respeito da toxicidade do benzeno no sistema nervoso central. O benzeno penetra facilmente no cérebro, onde é metabolizado a catecol. Como o catecol se auto-oxida em tampão fosfato no $\mathrm{pH}$ fisiológico, supôs-se que esse composto poderia ser tóxico para células gliais por gerar espécies reativas do oxigênio e quinonas. Nesse trabalho estudou-se a citotoxicidade do catecol para células de glioblastoma humano. O catecol foi tóxico após 72 horas e essa toxicidade relacionou-se com a formação de quinonas. O catecol a 230 $\mathrm{MM}$ matou metade das células em cultura. A toxicidade do catecol e a produção de quinonas foram inibidas por $100 \mathrm{U}$ de superóxido dismutase. Esses dados sugerem que a toxicidade induzida pelo catecol deve-se à produção extracelular de superóxido e quinonas reativas.

\section{unitermos}

Catecol

Citotoxicidade

1,2-diidroxibenzeno

Glioblastoma

Superóxido 


\section{Introduction}

Occupational hygienists have investigated the exposure to benzene ${ }^{(13)}$ in the petroleum industry because it causes lympho-haematopoietic cancer among workers. The wastewater generated by the petroleum industry contains an appreciable amount of benzene, toluene, ethylbenzene and xylene (BTEX) that requires specific treatment to avoid environmental contamination ${ }^{(15)}$ or to remove these compounds from the ground or surface water resources ${ }^{(6)}$. Certain tasks, such as the loading and unloading of petroleum products in the marine, railcars, trucks and so forth, produce a high risk of exposure to benzene ${ }^{(26)}$. Moreover, benzene is also present in tobacco smoke. The metabolism of benzene by human liver microsomes forms phenol, hydroquinone and catechol (1,2-dihydroxybenzene) $)^{(23)}$. Benzene, at concentrations up to $10 \mathrm{mM}$, was neither genotoxic nor cytotoxic toward peripheral blood mononuclear cells in vitro. However, its metabolites benzenetriol and catechol are genotoxic at micromolar concentrations ${ }^{(9)}$.

Catechol easily autoxidizes to form potentially toxic quinones and reactive oxygen species (ROS) that induce stress proteins in Acinetobacter calcoaceticus ${ }^{(2)}$. Trace elements in tobacco smoke may act as catalysts for the formation of ROS and various free radicals by redox cycling of catechol, thus greatly enhancing the potential for tissue damage ${ }^{(24)}$. Catechol at micromolar concentrations induces a time-dependent release of iron from ferritin in vitro and causes lipid peroxidation in rat brain homogenates ${ }^{(1)}$. Furthermore, catechol and cigarette smoke condensates are reported to induce oxidative regulation of protein kinase $C$ and influence the invasive capacity and metastatic spread of lung carcinoma cells ${ }^{(14)}$. Tobacco smoking is also a co-factor lowering the blood serum immunoglobulin concentration in subjects with occupational exposure to organic solvents containing BTEX(21). Generally speaking, chronic smoking and exposure to BTEX are relevant problems to human health. In addition, the use of tobacco regularly associated with inhalation of solvents among street children has been reported as a social problem in Brazil(10).

There is an increasing interest to study the toxicity of catechols toward cells from the central nervous system (CNS) since it has been speculated that the toxicity of these compounds is associated with neurodegenerative diseases. Among these cells astrocytes are the most numerous cellular elements in the CNS, where they play a critical role in physiological and pathological events. The dose-dependent toxicity of endogenous catechols like
L-3,4-dihydroxyphenylalanine (L-DOPA), dopamine and also other drugs bearing a catechol group like apomorphine is well-documented in in vitro cell studies ${ }^{(7,17,18)}$. However, there are few data concerning the toxicity of catechol toward glial cells. Although the human glioma cell line GL15 is poorly differentiated, these cells preserve many characteristics of astrocytes ${ }^{(20)}$ and proliferate rapidly in culture. Glioma cells have been largely used for the study of astrocyte properties ${ }^{(4)}$. In this study we evaluate the toxicity of catechol toward GL-15 cells and its relation with the production of superoxide by the measurement of mitochondrial dehydrogenases activity and quinones formation in cell cultures with and without superoxide dismutase (SOD) and catalase.

\section{Material and method}

\section{Material}

Catechol was from Riedel-de Haën, Buchs-Switzerland. SOD (EC 1.15.1.1) was purchased from ICN, OH, USA. Catalase (EC 1.11.1.6), 3-(4,5-dimethylthiazol-2-yl)2,5-diphenyltetrazolium bromide (MTT) and trypsin (EC 3.4.21.4) were purchased from Sigma MO, USA. Dulbecco's modified Eagle's medium (DMEM) was purchased from Cultilab, SP, Brazil. All other chemicals were of guaranteed grade. Catechol solution $(10 \mathrm{mM})$ was prepared in $0.01 \mathrm{M} \mathrm{HCl}$. All solutions were prepared with deionized water.

\section{Measurement of catechol autoxidation in a cell-free system}

Neutral aqueous solutions of catechol undergo spontaneous oxidative decomposition. Autoxidation is a multi-step reaction resulting in ROS and quinone derivatives formation. In the present study, the autoxidation rates were measured at $320 \mathrm{~nm}$ in $1 \mathrm{mM} \mathrm{HCl}, 50 \mathrm{mM}$ phosphate buffer (pH 7.4). The catechol oxidation (final concentration of $1 \mathrm{mM}$ ) was carried out with or without 17U SOD or 100IU catalase in a volume of $3 \mathrm{ml}$. Catechol oxidation was also measured by means of a Clark-type oxygen electrode fitted to an oxygen monitoring system (YSI model 53 oxygen monitor).

\section{Human glioblastoma GL-15 cell culture}

The GL-15 cell line of clonal origin was established by Bocchini et al., in $1991^{(3)}$. Cultures of these cells were prepared as previously described by Planchenault et al., in 


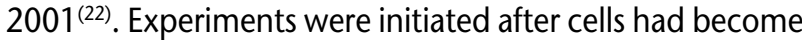
confluent. Cell cultures were divided into seven groups. The control group was treated with $2 \times 10^{-5} \mathrm{M} \mathrm{HCl}$, which was used as the solvent of catechol. The other six groups were treated with concentrations of catechol ranging between 100 and $1000 \mu \mathrm{M}$ for 72 hours. In each group, cells were seeded into six Petri dishes ( $35 \mathrm{~mm}$ in diameter) to obtain a final density of $3 \times 10^{5}$ cells/dish. In order to study the role of the production of superoxide on the toxicity of catechol, cells were treated with this compound in the presence of $100 \mathrm{U}$ SOD for 72 hours. Catalase at 500IU was used to assess the role of hydrogen peroxide in the catechol-induced toxicity. The catechol oxidation in the medium was monitored spectrophotometrically at $405 \mathrm{~nm}$, based on quinones and melanin-like pigment formation ${ }^{(18)}$. The cell viability was quantified by the conversion of yellow MTT to purple MTT formazan by living cell mitochondrial dehydrogenases ${ }^{(16)}$.

\section{Calculation}

The rates of oxygen consumption and formation of quinones were obtained from a linear regression plot. Linear regression was carried out by using the least square method. This calculation was also used to determine the concentration of catechol that killed $50 \%$ of cells $\left(\mathrm{IC}_{50}\right)$, since the plot was linear for catechol concentrations ranging between 100 and $500 \mu \mathrm{M}\left(\mathrm{y}=-0.6085 \mathrm{x}+63.99 ; \mathrm{r}^{2}=0.9927\right)$. Data obtained for the catechol oxidation in a cell-free system were compared by the Student's $t$ test. The significance of results obtained from toxicity studies was analyzed by ANOVA, with the Student-Newman-Keuls post hoc test.

\section{Results}

\section{Catechol autoxidation in a cell-free system}

The oxygen consumption during autoxidation of $1 \mathrm{mM}$ catechol was estimated quantitatively. Catechol, at $1 \mathrm{mM}$, oxidizes consuming oxygen in a rate of $1.2 \pm 0.3 \mu \mathrm{M} \cdot \mathrm{min}^{-1}$. From Figure 1 it can be seen that the addition of $17 \mathrm{U}$ SOD significantly inhibited oxygen consumption by $83.7 \%$. The addition of 100IU catalase did not inhibit catechol autoxidation. The rate of quinones formation was also decreased by $37 \%$ in the presence of $17 \mathrm{U}$ SOD (Figure 2) but no significant difference was found when $100 \mathrm{U}$ catalase was added to the system. Altogether, these data suggest that superoxide is produced during the oxidation of catechol. On the other hand, the production of hydrogen peroxide was not evidenced by the use of catalase.

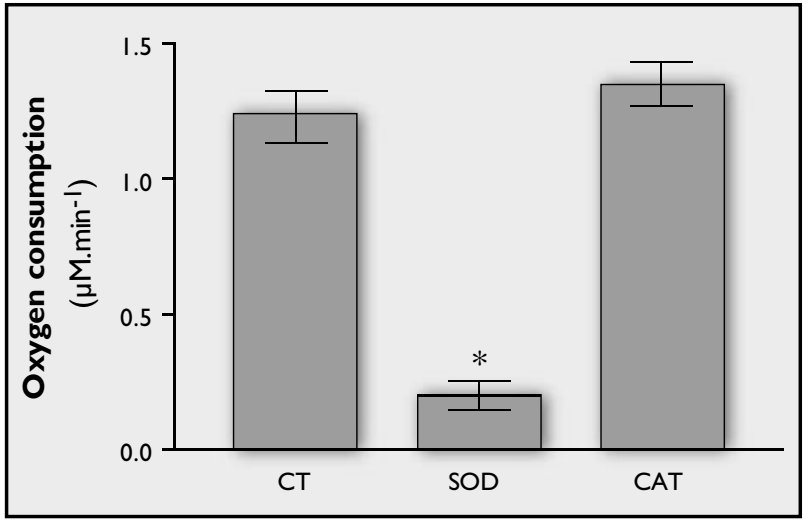

Figure 1 - Oxygen consumption during autoxidation of $1 \mathrm{mM}$ catechol in $1 \mathrm{mM} \mathrm{HCl}, 50 \mathrm{mM}$ phosphate buffer ( $\mathrm{pH} 7.4)$ at $37^{\circ} \mathrm{C}$. Catechol was tested alone (CT, $n=13$ ), in the presence of $17 \mathrm{U}$ superoxide dismutase (SOD, $n=3)$, or in the presence of $1001 \mathrm{U}$ catalase $(C A T, n=3)$. Each value represents the mean \pm SEM; ${ }^{*} p<0.0005$

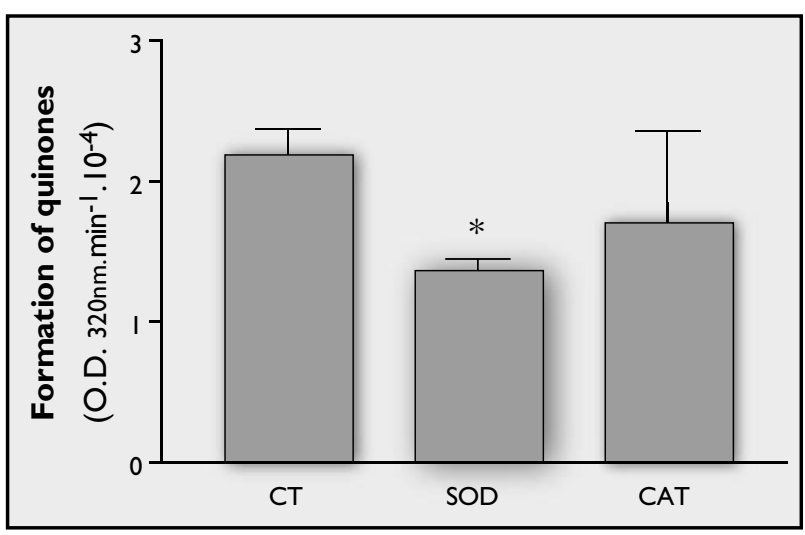

Figure 2 - Formation of quinones during autoxidation of $1 \mathrm{mM}$ catechol in $1 \mathrm{mM}$ $\mathrm{HCl}, 50 \mathrm{mM}$ phosphate buffer ( $p H$ 7.4). Catechol was tested alone (CT, $n=6)$, in the presence of $17 \mathrm{U}$ superoxide dismutase (SOD, $n=4)$, or $1001 \mathrm{U}$ catalase (CAT, $n=3)$. Each value represents the mean $\pm S E M ;{ }^{*} p<0.05$

\section{Catechol toxicity towards GL-15 cells}

In order to determine the nature of cytotoxicity induced by catechol, GL-15 cells were treated for 72 hours with several concentrations of this compound. As shown in Figure 3, catechol treatment resulted in a marked loss of cell viability in a dose-dependent manner. The $\mathrm{IC}_{50}$ value for catechol-induced cytotoxicity towards GL-15 cells after 72 hours was $230 \mu \mathrm{M}$. Autoxidation of catechol also formed quinones in the culture medium in a dosedependent manner (Figure 3). The cytotoxic effects induced by catechol appeared to correlate with the formation of quinones in cell cultures.

The addition of $100 \mathrm{U}$ SOD to cells treated with $300 \mu \mathrm{M}$ catechol for 72 hours inhibited the formation of quinones by $63.5 \%$ (Figure 4 ). However, the addition of the same amount of heat-inactivated SOD (iSOD) or 500IU catalase did not inhibit catechol oxidation. Moreover, the addition of 
100U SOD combined with 500IU catalase did not increase the inhibition induced by SOD alone. The presence of SOD at $100 \mathrm{U}$ also significantly prevented catechol-induced cytotoxicity towards GL-15 cells (Figure 5). Cell survival increased from $49.5 \% \pm 4.2 \%$ in cells treated with $200 \mu \mathrm{M}$ catechol $(n=5)$ to $71.9 \% \pm 3.9 \%$ in the group incubated in the presence of $100 \mathrm{U}$ SOD $(n=5)$. Cell survival also increased from $47.4 \% \pm 6.5 \%$ in the group treated with $300 \mu \mathrm{M}$ catechol $(n=5)$ to $61.6 \% \pm 6.9 \%$ in that incubated in the presence of SOD $(n=4)$. The addition of iSOD or $500 I U$ catalase did not protect the cells. Once again, SOD combined with catalase did not increase the protective effect of SOD.

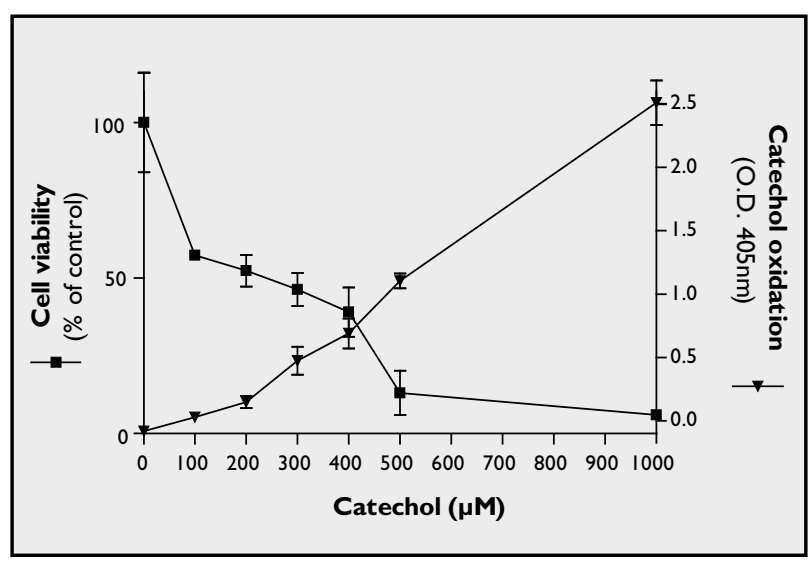

Figure 3 - Concentration-response curves for catechol-induced cytotoxicity and quinones formation in $\mathrm{GL}-15$ cell cultures after $72 \mathrm{~h}$. Cell viability ( $\mathbf{\square})$ was determined by the MTT test and expressed as a percentage of control treated with $2 \times 10^{-5} \mathrm{M} \mathrm{HCl}$. Each point represents the percentage of cell viability after treatment with catechol in several concentrations. The formation of quinones during the autoxidation of catechol was also measured by spectrophotometry at $405 \mathrm{~nm}(\mathbf{v})$ Data are represented by the mean $\pm S D, n=5$

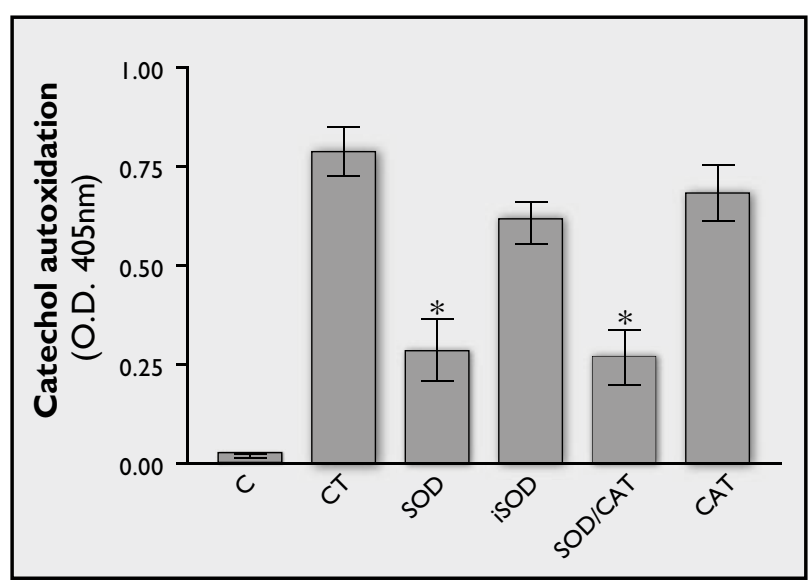

Figure 4 - SOD inhibits the formation of quinones in cultures of GL-15 cells. Cells were incubated for 72 hours with: $2 \times 10^{-5} \mathrm{M} \mathrm{HCl}(\mathrm{C}) ; 300 \mu \mathrm{M}$ catechol alone (CT) or in the presence of $100 U$ SOD (SOD), the same amount of heat-inactivated SOD (iSOD), 100 U SOD combined with $5001 \mathrm{U}$ catalase (SOD/CAT) or $5001 \mathrm{U}$ catalase (CAT). Data are represented by the mean $\pm S D, n=6$; ${ }^{*} p<0.0001$, when compared to cells treated with catechol alone

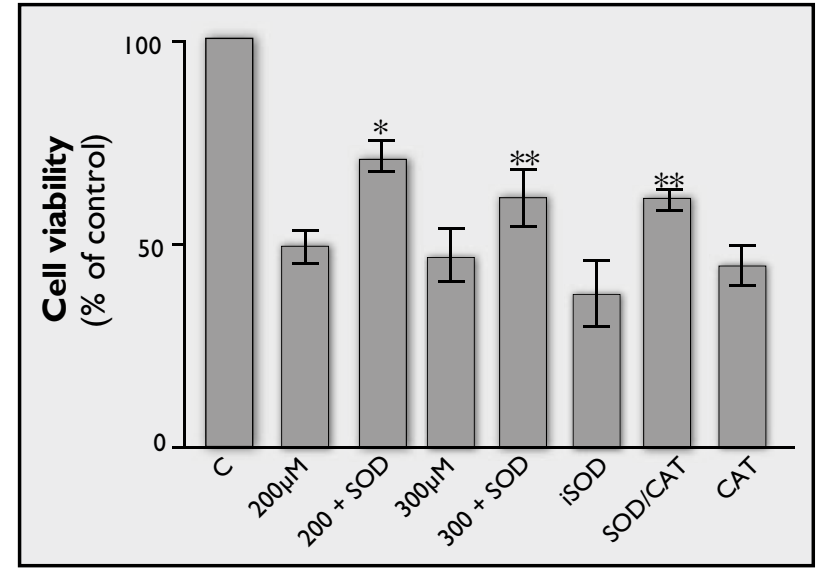

Figure 5 - Effect of superoxide on catechol-induced cytotoxicity towards GL-15 cells. Cells were incubated for 72 hours with $2 \times 10^{-5} \mathrm{M} \mathrm{HCl}(\mathrm{C})$ or with two different concentrations of catechol (200uM or 300uM). Prevention of cytotoxicity induced by these concentrations was observed in the presence of $100 U$ SOD (SOD). Cells were also incubated with $300 \mathrm{\mu M}$ catechol in the presence of heat-inactivated SOD (iSOD), $100 U$ SOD combined with $5001 \mathrm{U}$ catalase (SOD/CAT) and $5001 \mathrm{U}$ catalase (CAT). Data are represented by the mean of the percentage of cell viability $\pm S D, n=6$; ${ }^{*} p<0.0001$, when compared with cells incubated with $200 \mu \mathrm{M}$ catechol; ${ }^{* *} p<0.02$, when compared with cells incubated with $300 \mu \mathrm{M}$ catechol

\section{Discussion}

The present results indicate that the reaction between catechol and oxygen is inhibited by SOD in a cell-free system. One of two phenolic hydroxyl groups of the catechol molecule is ionized in alkaline solutions and, therefore, electron transfer from this ionized group to a dissolved oxygen occurs easily ${ }^{(27)}$. Consequently, this results in superoxide formation during the catechol autoxidation. On the other hand, the formed superoxide reacts with catechol accelerating the formation of quinones, since this reaction was also inhibited by SOD. Since catalase did not inhibit the oxygen consumption or the quinone formation, this means that superoxide and not peroxide was the main ROS formed in the autoxidation. The oxidative property of catechol seems important because endogenous catechols like catecholamines and catechol estrogens $s^{(5)}$ are produced in mammal brains and other tissues. Thus, catechol oxidation can be used for structure-activity relationship studies.

Reactive species produced during the autoxidation of catechols may also be toxic to cells. In this study catechol was toxic towards human GL-15 cells after 72 hours and this was related to the formation of quinones. The $\mathrm{IC}_{50}$ value for catechol-induced cytotoxicity was $230 \mu \mathrm{M}$. Some drugs that contain catechol moieties, like apomorphine, also have the same oxidative properties ${ }^{(8)}$. We have found that apomorphine-induced toxicity towards glial C6 cells depends on time and dose with an $\mathrm{IC}_{50}$ value of $200 \mu \mathrm{M}$ 
after 48 hours $^{(7)}$. Catecholamines are also toxic at high concentrations $(>50-100 \mu \mathrm{M})^{(25)}$. The $\mathrm{IC}_{50}$ values for LDOPA- and dopamine-induced cytotoxicities towards SH-SY5Y neuroblastoma cells were 194 and $184 \mu \mathrm{M}$ respectively, after 24-hour drug exposure ${ }^{(17)}$. Thus, it seems that molecules bearing a catechol group are toxic to cells from the CNS in vitro. However, catechols at low concentrations $(1 \mu \mathrm{M})$, like norepinephrine and catechol, provide protection to dopaminergic neurons in mesencephalic cell cultures ${ }^{(25)}$.

In this study it has been shown that SOD protected cells against catechol-induced cytotoxicity and also inhibited quinones formation. Superoxide is the most common intracellular free radical leading to the formation of other reactive' cell-damaging species, when present in excessive amounts. It is well accepted that SOD represents the first line of defense against oxygen toxicity. SOD also protected SH-SY5Y neuroblastoma cells against the neurotoxic properties of L-DOPA and dopamine-related compounds ${ }^{(17)}$. In the present study, catalase did not prevent catecholinduced cytotoxicity towards GL-15 cells. Similarly, catalase had no effect on semiquinone radicals formation in dopamine oxidation, although this enzyme showed a small preventive effect against dopamine-induced toxicity towards SH-SY5Y cells ${ }^{(17)}$. It has been determined both by animal and clinical studies that SOD protects the brain against injury by ischemic stroke and trauma ${ }^{(12)}$.
To increase the efficacy of L-DOPA in the treatment of Parkinson's disease, this agent is sometimes associated with inhibitors of catechol-0-methyltransferases (COMT, EC 2.1.1.6) and amino acid decarboxylase (AADC, EC 4.1.1.28). These inhibitors also present catechol groups in their structures. This association between L-DOPA with COMT or AADC inhibitors increased protein carbonyls, lipid peroxidation and oxidative DNA damage levels in the cerebral cortex of normal cynomologus monkeys ${ }^{(19)}$. Consistent with these results, microdialysis experiments carried out in rats showed that the association between L-DOPA, carbidopa (an AADC inhibitor) and tolcapone (a central and peripheral COMT inhibitor) increased striatal hydroxyl radical production. Thus, it is thought that cell death induced by catechols involves oxidative damage.

In conclusion, these results revealed a possible mechanism of catechol-induced cytotoxicity in glioblastoma GL-15 cells. Catechol, which is a metabolite of benzene, probably exerts cytotoxicity mainly due to the generation of superoxide and quinones during its autoxidation.

\section{Acknowledgements}

The authors are grateful to Dr. S. I. Sardi and Dr. G. S. Campos for the use of their laboratory during some experiments. We thank Dr. E. J. de-Castro-e-Silva, Mr. Drew Bradford and Mrs. Elli T. M. Lewis for revising this manuscript.

\section{References}

I.AGRAWAL, R. et al. Release of iron from ferritin by metabolites of benzene and superoxide radical generating agents. Toxicology, v. I68, p. 223-30, 200।

2. BENNDORF, D. et al. Protein synthesis patterns in Acinetobacter calcoaceticus induced by phenol and catechol show specificities of responses to chemostress. FEMS Microb Lett, v. 200, p. 247-52, 2001

3. BOCCHINI, V. et al. Changes in GFAP and karyotype during culturing of two cell lines established from human glioblastoma multiform. Cell Tissue Res, v. 265, p. 73-81, |991.

4. BRISMAR, T. Physiology of transformed glial cells. Glia, v. I5, p. $231-43,1995$

5. COUMOUL, X.; BAROUKI, R. Génotoxicité des métabolites des oestrogènes et cancers. Med Sci, v. I8, p. 86-90, 2002.

6. CUNNINGHAM, J. A. et al. Enhanced in situ bioremediation of BTEX-contaminated groundwater by combined injection of nitrate and sulfate. Environ Sci Technol, v. 35, p. I663-70, 2001

7. EL-BACHÁ, R. S. et al. Toxic effects of apomorphine on rat cultured neurons and glial C6 cells, and protection with antioxidants. Biochem Pharmacol, v. 6I, p. 73-85, 2001.
8. EL-BACHÁ, R. S. et al. Is apomorphine neurotoxic? Biogenic Amines, v. 16, p. 463-71, 2001.

9. FABIANI, R. et al. Influence of culture conditions on the DNAdamaging effect of benzene and its metabolites in human peripheral blood mononuclear cells. Environ Mol Mutagen, v. 37, p. $1-6,2001$

10. FORSTER, L. M. K. et al. Drug use among street children in Southern Brazil. Drug Alcohol Depend, v. 43, p. 57-62, 1996.

I I. GERLACH, M. et al. The central catechol-O-methyltransferase inhibitor tolcapone increases striatal hydroxyl radical production in L-DOPA/carbidopa treated rats. J Neural Transm, v. I08, p. I89-204, 2001.

12. GILGUN-SHERKI, Y. et al. Antioxidant therapy in acute central nervous system injury: current state. Pharmacol Rev, v. 54, p. 27|-84, 2002

13. GLASS, D. C.; GRAY, C. N. Estimating mean exposures from censored data: exposure to benzene in the australian petroleum industry. Ann Occup Hyg, v. 45, p. 275582,2001 .

14. GOPALAKRISHNA, R. et al. Tobacco smoke tumor promoters, catechol and hydroquinone, induce oxidative regulation of protein kinase $C$ and influence invasion and metastasis 
of lung carcinoma cells. Proc Natl Acad Sci USA, v. 91, p. 12233-7, 1994.

15. GUNUKULA, R. V.; TITTLEBAUM, M. E. Industrial wastewater treatment by an advanced oxidation process. J Environ Sci Health Part A Tox Hazard Subst Environ Eng, v. 36, p. 307-20, 2001 .

16. HANSEN, M. B. et al. Re-examination, and further development of a precise and rapid dye method for measuring cell growth/ cell kill. J Immunol Methods, v. I19, p. 203-10, 1989.

17. HAQUE, M. E. et al. Apoptosis-inducing neurotoxicity of dopamine and its metabolites via reactive quinone generation in neuroblastoma cells. Biochim Biophys Acta, v. 1619, p. 39-52, 2003.

I 8. LAI, C.T.;YU, P.H.Dopamine-, and L- $\beta$-3,4-dihydroxyphenylalanine hydrochloride (L-Dopa)-induced cytotoxicity towards catecholaminergic neuroblastoma SH-SY5Y cells. Biochem Pharmacol, v. 53, p. 363-72, 1997.

19. LYRAS, L. et al. Chronic high dose L-DOPA alone or in combination with the COMT inhibitor entacapone does not increase oxidative damage or impair the function of nigro-striatal pathway in normal cynomologus monkeys. J Neural Transm, v. I09, p. 53-67, 2002.

20. MORETTO, G. et al. A time-dependent increase in glial fibrillary acidic protein expression and glutamine synthetase activity in long-term subculture of the GLI5 glioma cell line. Cell Mol Neurobiol, v. 17, p. 509-19, 1997.

21. MOSZCZYNSKI, P. The effect of cigarettes smoking on the indexes of immunity and acute phase reaction in subjects with occupational exposure to organic solvents. Cent Eur J Public Health, v. I, p. 4I-5, 1993.

22. PLANCHENAULT, T. et al. Differential expression of laminin and fibronectin and of their related metalloproteinases in human glioma cell lines: relation to invasion. Neurosci Let, v. 299, p. |40-4, 2001.

23. POWLEY, M. W.; CARLSON, G. P. Species comparison of hepatic and pulmonary metabolism of benzene. Toxicology, v. 139, p. 207-17, 1999.

24. STOHS, S. J. et al. Toxicity of trace elements in tobacco smoke. Inhal Toxicol, v. 9, p. 867-90, 1997.

25. TROADEC, J. D. et al. Noradrenaline provides long-term protection to dopaminergic neurons by reducing oxidative stress. J Neurochem, v. 79, p. 200-10, 2001.

26.VERMA, D. K. et al. Benzene and total hydrocarbons exposures in the downstream petroleum industries. AlHAJ, v. 62, p. 176-794, 2001.

27. YOSHIOKA, H. et al. Spectral simulation of the ESR spectra of polyphenol radicals formed by reaction with hydroxyl radical. J Phys Chem A, v. I07, p. I 127-32, 2003.

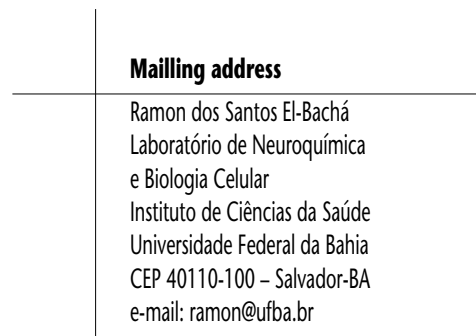

